\title{
Towards a Model of Attitudes and Character Learning Training Needed by Teachers
}

\begin{abstract}
Badeni $^{*}$
Doctoral Education Study Program, University of Bengkulu

*Corresponding Author. Email: badeni@unib.ac.id

ABSTRACT

A lot of training models of attitude and character learning have been applied for the training of Indonesian teachers; however, the majority of them still feel confused about how instill values in their students and shape children's attitudes and characters. Research and development method was applied in this study. The sample population of this study consisted of (a) $5 \%$ of the elementary school teachers in Bengkulu Province selected proportionally and randomly, and (b) all the teacher trainers of Bengkulu Province Education Quality Assurance Agency. Data was collected through a forum discussion group and inventory instruments. After analyzing data, the researchers concluded, firstly, training models of attitudes and character learning applied so far (a) are only able to improve the cognitive level of the teachers in remembering and a little at the level of understanding, application and analysis; (b) have not been able to improve the skills needed by the teacher in shaping the attitudes and character of students. Secondly, training models of attitudes and characters needed by the teachers (a) are training models that can develop the cleverness of teachers to suit their needs while working in the field (b) have to take on the form of IN - ON (clinical supervision) - IN.
\end{abstract}

\section{Keywords: Attitudes and character, Training model, Teachers'needs, Cognitive level, Learning skill.}

\section{INTRODUCTION}

Education of values, attitudes, and characters in educational institutions needs to receive a lot of attention, and increase both in intensity and quality. Attitude and character education is a school program that involves collaboration with other community institutions to shape adolescent behavior [1]. Attitude and character education are various interventions directly or indirectly from various institutions that affect a person's values, attitudes, and character development, the ability to think about a problem or a person's opinion is right or wrong [2]. In practice, the mass media, religious communities, cultures, youth, peer groups, volunteer organizations, and especially families, have a significant influence on character building [3]. Character education emphasizes the development of habits and dispositions as prerequisites for moral people [4]. Moral education is helping children and adolescents to acquire a set of beliefs and values about what is right and wrong [5]. In general, attitude and character education is a process of teaching general attitudes, beliefs, and behaviors that are important for people to develop into responsible citizens [6]. In other words it can be said that the education of moral values, attitudes, and character, is a learning method that encourages the development of ethical and responsible individuals by teaching good values that humans should have. The main purpose of moral education, attitude, and character education is to form human intelligence to think logically and critically about moral issues, and the actual moral opinion possessed by individuals [7]. In this regard, formal educational institutions function as a forum for formal guidance for children and adolescents both in increasing the intensity and quality of education towards values, morals, attitudes, and characters [8]. The Indonesian government welcomes this function by revealing the formation of attitudes, morals and character of the younger generation as the main goal to be realized in the national curriculum, by choosing a scientific approach [9]. The problem is that even though the government has conducted teacher training using this approach, the level of teacher understanding of authentic assessment is still low. There are still many teachers who have difficulty in implementing character learning, developing assessment instruments, integrating assessment systems, and writing final reports [10]. This illustrates that the training model and approach chosen have not had a significant effect on the level of teacher understanding related to these aspects, especially in character learning. 
Another problem that occurs is that the learning to utilize the scientific approach has not been fully able to reach the main objectives in the core competencies 1 and 2 in the national curriculum [11]. Studies of various theories that try to achieve, by way of the scientific learning approach, the educational goals of the expected attitude, moral, and character values, where students have not formed attitudes and characters as desired by the national curriculum.

Based on the findings, it seems that further investigation is needed into (1) how the level of understanding of the teachers in choosing and implementing learning to develop the attitudes and character of students according to the goals of attitudes and character that are expected to innovate the national curriculum; (2) what teachers' training needs are so that they can improve the attitude and character of students; (3) training models that consider what should be done by trainers to improve the ability of primary school teachers in selecting and implementing a teachinglearning/instructional system that can develop attitudes and character.

\section{RESEARCH METHODS}

In this study, researchers used Research and Development (R\&D) developed by [12]. The sample population of this study consisted of (a) $5 \%$ of the elementary school teachers from nine districts and one city in Bengkulu Province selected proportionally and randomly, and (b) all the teacher trainers of the Bengkulu Province Education Quality Assurance Agency. Data was collected using forum group discussion (FGD) techniques and inventory instruments.

Preliminary research was conducted in the form of FGD. During the FGD, the researchers talked with elementary school teachers and teacher trainers about (1) the level of understanding of the teachers in choosing and implementing learning to develop the attitudes and characters of students in accordance with the attitude and character goals that are expected to innovate the national curriculum; (2) what teachers need from training in order to be able to develop the attitude and character of students; (3) training models, that is, what should be done by trainers to improve and develop the ability of primary school teachers in selecting and implementing learning models that can develop attitudes and character. The result of this preliminary research was then used as a basis for developing a model. Inventory instruments were arranged in the form of tests and observation checklists to express teachers' understanding of curriculum innovation and changes in student attitudes and character in relation to the application of attitude and character training models. The collected data was analyzed descriptively and qualitatively. The results of data analysis through the instrument were used as a basis for developing better models for learning attitude training and teacher training in learning attitudes and characters for students.

\section{RESULTS AND DISCUSSION}

\subsection{FGD Result Data}

Based on the results of the FGD, both the training participants who received training with the lecture model, the IN ON IN model, and the assistance model, were asked the question "Do you feel that you gained full understanding and skills of all the materials that were taught through the training process?" They stated their feeling as in Table 1

Table 1. FGD Result Data

\begin{tabular}{|l|l|}
\hline $\begin{array}{l}\text { Training } \\
\text { Model }\end{array}$ & \multicolumn{1}{c|}{ Results that Respondents feel } \\
\hline $\begin{array}{l}\text { Lecturin } \\
\text { g model }\end{array}$ & $\begin{array}{l}\text { 88\% of them felt that they only obtained very general knowledge and general understanding of all the material being } \\
\text { trained but felt confused about how to apply the training results in the learning of attitudes and characters in the } \\
\text { learning process, analysis and synthesis of the learning process and results, evaluate the process, and evaluate the } \\
\text { character learning outcomes of students. }\end{array}$ \\
\hline $\begin{array}{l}\text { IN - ON } \\
\text { - IN }\end{array}$ & $\begin{array}{l}\text { a) } 81 \% \text { of respondents felt that they had not obtained the knowledge, understanding, or way of application related to } \\
\text { all the material being taught, were still confused about how to apply learning attitudes and characters both in the } \\
\text { learning process and in evaluating student learning outcomes towards attitudes and character; (b) only 5\% of } \\
\text { respondents feel they understand and are able to apply learning attitudes and characters in class, although they also } \\
\text { experience difficulties in analyzing and evaluating learning processes and outcomes. The rest, feel they understand } \\
\text { but still have difficulty implementing character learning in class. }\end{array}$ \\
\hline $\begin{array}{l}\text { Assistanc } \\
\text { e model }\end{array}$ & $\begin{array}{l}\text { ?" (a) 75\% felt they had not fully gained the knowledge and understanding of the material being taught and that the } \\
\text { ability to implement attitudes and character learning were still mechanical, in the sense that the attitudes and character } \\
\text { teaching they were doing were still like patterns exemplified by the trainer - both in the learning process and the ways }\end{array}$ \\
\hline
\end{tabular}


to evaluate the development of children's attitudes and character. Furthermore, they still found it very difficult if they were told to analyze and synthesise the learning process and results, evaluate the process and the results of attitudes and character learning on students; (b) $25 \%$ of them felt they understood and that they were able to apply this information to teach attitudes and characters in the classroom, even though, if told to analyze the process and results of attitudes and character learning, they still experienced difficulties. Moreover, they did not understand if and how to develop learning models of attitudes and characters that are in line with the core competencies and basic competencies that should be achieved

\subsection{Questionnaire Results Data}

Two set of data were obtained from questionnaires; namely data about teachers' cognitive level of attitudes and character learning and data on the training needs about teachers' character learning.
The method used to collect data about the level of understanding of the results of learning attitudes and character training involved adopting the cognitive levels found by [13]. Table 2 illustrates the teachers' percentage of data needed by the teacher in attending attitude and character learning training.

Table 2: Percentage of data needed by the teacher in attending attitude and character learning training

\begin{tabular}{|l|c|}
\hline \multicolumn{1}{|c|}{ Aspects of learning materials attitude and character } & \\
\hline The essence of learning attitude and character & $72 \%$ \\
\hline Theory of learning attitude and character & 76 \\
\hline Steps for learning attitude and character & 75 \\
\hline Strategies and techniques of learning attitude and character & 78 \\
\hline Preparation of learning plans for attitude and character & 80 \\
\hline The learning system of attitude and character evaluation & 77 \\
\hline Development of instruments for observing attitudes and character & 79 \\
\hline The practice of learning attitudes and character & 78 \\
\hline
\end{tabular}

Table 3: The teachers ability level with respect to the results of the training on attitudes and character learning

\begin{tabular}{|c|c|c|c|c|c|c|}
\hline \multirow{2}{*}{$\begin{array}{l}\text { Aspects of Learning Materials Attitude and Character } \\
\text { Training }\end{array}$} & \multicolumn{6}{|c|}{$\begin{array}{l}\text { Percentage of teachers' level of ability with respect the results of } \\
\text { attitude and character learning training }\end{array}$} \\
\hline & $\operatorname{Rem}_{\mathrm{g}}^{\text {Rememberin }}$ & $\begin{array}{l}\text { Understandi } \\
\text { ng }\end{array}$ & $\begin{array}{l}\text { Applicatio } \\
n\end{array}$ & $\begin{array}{c}\text { Analysi } \\
\mathrm{s}\end{array}$ & $\begin{array}{l}\text { Evaluati } \\
\text { on }\end{array}$ & $\begin{array}{c}\text { Cre } \\
\text { atin } \\
\text { g }\end{array}$ \\
\hline The essence of learning attitude and character & 60 & 30 & 6 & 4 & 0 & 0 \\
\hline Theory of learning attitude and character & 65 & 35 & 5 & 0 & 0 & 0 \\
\hline Steps of learning attitude and character & 68 & 25 & 7 & 0 & 0 & 0 \\
\hline $\begin{array}{l}\text { Strategy and technique of learning attitude and } \\
\text { character }\end{array}$ & 54 & 37 & 9 & 0 & 0 & 0 \\
\hline Preparation of lesson plans for attitude and character & 72 & 20 & 8 & 0 & 0 & 0 \\
\hline $\begin{array}{l}\text { The evaluation system in learning attitudes and } \\
\text { characters }\end{array}$ & 67 & 25 & 8 & 0 & 0 & 0 \\
\hline $\begin{array}{l}\text { Development of attitude and character observation } \\
\text { instruments }\end{array}$ & 66 & 22 & 12 & 0 & 0 & 0 \\
\hline Application of attitude and character learning & 78 & 18 & 4 & 0 & 0 & 0 \\
\hline Average & 71,9 & 32,38 & 23,75 & 10,1 & 0 & 0 \\
\hline
\end{tabular}

Based on the results of the FGD with the teachers who were trained using the lecturing model, it was found that $88 \%$ of them felt (a) they only gained very general knowledge and understanding from all the material being trained; (b) confusion about how to apply the results of the training in the implementation of character learning throughout the learning process, analysis and synthesis of learning processes and results, evaluating the process and in evaluating the results of character learning on students. The rest (12\%) stated that they (a) felt they gained knowledge and understanding of the material presented by the trainers, but (b) still felt difficulties in applying the results of the training to character learning in the learning process, analysis, and process synthesis and learning outcomes, evaluating the process and evaluating the results of character learning on students. This means that the implementation of training conducted using lecture models has not met the targets as expected in the training objective. Thus, it can be understood why this 
model has not been able to effectively achieve the training objectives. Lecturing mainly involves the trainees only receiving information on all training material on attitudes and character learning through slideshows and explanation of what is displayed orally from trainers. In this model of training, the trainer does not get the opportunity to engage all the senses of the trainees in full. Out of the five senses, only hearing is engaged, while the senses of sight, motor senses, feelings, the sense of smell,taste, and sense of touch (including motion) are less active - if at all. They also lack feedback on their learning outcomes. This didn't give trainees the opportunity to analyze and evaluate their learning outcomes. In the learning process, the more both students and trainees use their senses, the more complete information or knowledge they will receive. The more complete information or knowledge they learn, the more it is possible for them to construct old knowledge and new knowledge into deep and practical knowledge. As [14] stated, this deep knowledge will be accquired if learners engage in such higher-order thinking tasks as analysis, synthesis, and evaluation, so they are immersed in experiences of meaning-making inquiry, action, imagination, invention, interaction, hypothesizing and personal reflection; they engage in deliberate practice as promoting practice focused on learning from errors; and they avoid misconceptions constructed by learners [15]

Besides, training through lecturing models paid little attention to adult characteristics in learning; adult learning must emphasize the benefits of personal training for trainees and the contents that can be applied to the real-life situations of the trainees [16]. In the process of learning, adults enjoy speaking to one another - not just listening to the sound of the trainer's voice; they also need feedback and constructive criticism; they need training methods that require active participation, provide immediate feedback on practice, either from self-feedback, peer feedback or trainer feedback [15]. These all mean that adults need that course contents that provide them with benefits and can be practiced in their own lives or where they are working. Besides, adult learners want gentle, constructive criticism. Sensitive feedback and constructive criticism will help trainees' correct errors and reinforce good behaviors while providing timely corrective feedback leads to successful learning and mastery of content and skills [16].

In other words, adult learners would acquire deep knowledge or higher abilities and skills to teach students attitude and character, if the adult learners have a lot of opportunities to have closed feedback, especially from their trainers, and to speak to each other. Given these opportunities, they will be able to construct their old experiences and their new information or experiences through practicing activities of analyzing, synthesizing, evaluating, and creating a new concept to practice in in their workplace.

This is not the case with IN ON IN models. Based on the results of the interview with trainees trained through IN ON IN, it was found that (a) $81 \%$ of them said they felt that they had not yet received the knowledge, understanding, and full application of all the training material. They also still felt confused about how to apply the learning process of attitudes and character, both with respect to the learning process and how to evaluate student learning outcomes. They felt it was more difficult if they had to do an analysis process, evaluation, and development to develop learning according to the competencies they are supposed to achieve. (b) 5\% of them felt they understood and would be able to apply this material to teaching attitudes and characters in the classroom, even though they also experienced difficulties in analyzing,and evaluating learning processes and outcomes of the attitudes and character learning. The rest stated that they felt they understood but still felt difficulties in applying character learning in the classroom.

Even though the IN ON IN model give trainees the opportunity to practice the knowledge they obtained in the first IN session at work, they lack the opportunity to receive full guidance or direct feedback when in the field. Guidance or feedback provided by trainers to trainees is only on what they feel has not been understood or issues reported by trainees from their practice in the field. Trainees lack guidance on everything they should know including whether the steps that they are taking in the field are correct or not. Thus they also do not know for certain whether they are doing it correctly or not. As a result, trainees have doubts about carrying out their duties in the field. In connection with this, it is not surprising that trainees still feel confused about how to apply learning attitudes and characters to both the learning process and how to evaluate student learning outcomes. They feel more difficult if they have to do an analysis process, evaluation and must develop learning according to the competencies they are supposed to achieve. This is because even though they get guidance during practice in the field $(\mathrm{ON})$, the guidance they receive is only based on what they report to the trainers when they are present. When trainers visit trainees in the field, they rarely observe what trainees are practicing in the field, so that trainers do not fully understand whether the trainees have mastered both theoretically and practically what should be done in the field. As a result, the trainers only resolve the problems reported by the trainees, and the suggestions they offer might not be 
valid as the trainers would not be fully informed of what has or has not been mastered by the trainees, both conceptually and practically. This is in line with what was said by [17]. All this means that trainees will gain understanding and skills in full if they gains experience and guidance from the trainer as a whole.

The trainees who received training with assistance models $(75 \%)$ felt they knew what they were being taught but had not yet fully gained the knowledge and understanding of the material they were taught while their ability to carry out learning attitudes and character was still mechanical in the sense that the teaching of attitudes and character they was still like patterns exemplified by the trainer, both in the learning process and ways to evaluate the development of children's attitudes and character. Even they still found it very difficult to analyze and synthesize learning processes and results, evaluate the process, and the results of character learning on students. Only $25 \%$ trainees felt they understood and would be able to apply this knowledge to teach students attitudes and character in the classroom, although they still experienced difficulties when told to analyze the process and results of learning attitudes and characters from the learning process they were applying.

This happened because, during the training process, the trainers only gave examples, while the trainees were only told to practice what was exemplified by the trainer. This means that the training process only occurs mechanically. As the trainees only had the opportunity to practice mechanically the acquired abilities occurred only mechanically. This means trainees gain less experience of exploring what they are learning. A further consequence of this is that when they were faced with problems and in different situations and conditions, they experienced confusion. Learning will succeed if the trainee experiences it in full both in the cognitive and sensory processes. In the cognitive process, this is achieved if the trainee experiences the use of the power of higher-order thinking by always answering questions commonly called $5 \mathrm{~W}+1 \mathrm{H}$ (What, Why, Who, When, Where, and How). When learning in this way, trainees always concentrate on answering these questions - what they are learning, why they should be like this, how to do it, who can or should carry it out, where it is done and when it is done.

In terms of sensory learning, a person will succeed if he uses all his senses. The more trainees use all the senses they have, the better the level of learning results will be. This is in line with what was theorized by [18] in his cone of experience. He mentioned "that learners retain more information by what they 'do 'as opposed to what is 'heard', 'read'or 'observed'". He mentioned that the most dramatic amount of retention, retaining
$90 \%$ of the information, comes through what we say and do. The more concrete the learning, the more students are actively involved; the more abstract, and the less they are involved means less cognitive and affective learning.

It can be concluded that a training process will produce the best results if trainees have the opportunity to learn in a way which enables them to be actively involved in cognitive, affective, psychomotor processes and gain good luck in the learning process.

Table 3 shows the average level of cognitive ability of teachers with respect to attitude and character training materials. The average cognitive level of the teachers with respect to attitude learning material and character were $71.9 \%$ at the level of remembering; 32 , $38 \%$ for the level of understanding (understanding); $23.75 \%$ for the level of application (application) and the analysis level was $10.1 \%$. The level of evaluation (evaluation) and of creation (creating) were at $0 \%$. The data illustrates that the cognitive level of the majority of teachers with respect to the attitude and character learning outcomes were still at a low level, namely at the level of remembering (remembering), and, at a higher cognitive level, mastery was even lower; while no teachers had a cognitive level at the level of evaluation (evaluation) or creation of the attitudes and character training results. This means that these curriculum innovation training models (lecturing models, IN ON IN models and assurance models) are not appropriate ways a teacher should receive training. This is because the training models are designed based on the training objectives and targets desired by the trainers, not the needs of the trainees and how trainees who are adults learn. [19] trainees should be (1) involved in the planning and evaluation process relating to their own learning (2) learning material based on the needs and elevation of the world of work; (3) actively involved in the learning process; and (4) oriented to the problems they might face rather than training material. Relating to the fourth application of the principle, [20] explained that training should (1) be carried out by explaining why something needs to be learned; (2) explain the relevance of training to the needs of the world of work; (3) pay attention to the needs and level of needs of the trainees; (4) provide trainees with total direct feedback in practice in the field; and (5) provide opportunities for trainees to become actively involved in the learning process. This last principle agrees with [20] that, in the learning process, it is necessary to apply an active learning approach, namely learning that better trains the trainees' skills or demanding that trainees do something, provide high-level thinking and thinking rather than transmitting the information. 


\section{CONCLUSION}

The results of this study showed that attitude and character learning training done in the form of lecturing, IN ON IN and assistance models (a) can only improve the cognitive level of teachers in learning attitudes and characters at a low level, namely at the level of remembering and at least at the level of understanding, application, and analysis; (b) have not been able to improve the cognitive level of teachers at the level of evaluation and creation; and (c) have not been able to improve the skills needed by teachers in shaping the attitudes and character of students. The learning model of attitudes and character learning needed by teachers is a training model (a) that can improve the ability of teachers, (i) according to their needs, (ii) by getting them higher level of thinking (b) in the form of IN - ON (clinical supervision) - IN by always challenging them to answer $5 \mathrm{~W}+1 \mathrm{H}$ questions, and to complete mentoring as they practice in the field will allow teachers to have cognitive abilities from the low to the highest level (understand, apply, analyze, synthesize, evaluate and create) about the learning attitudes and character of students.

\section{ACKNOWLEDGMENTS}

Firstly, Authors gratefully acknowledge the Directorate of higher education, Indonesia ministry of research, technology and higher education that provided the fund for this research project. Secondly, we would like to thank all of the heads of the Research and Social Service Board Bengkulu University who coordinated and facilitated administration of this research project. Lastly, we would like to thank all the teacher Trainers of Bengkulu Province, Centre County, and Seluma County, who helped us develop and complete this project through their participation and cooperation

\section{REFERENCES}

[1] White, R., Building Schools of Character: The Development, Implementation, and Evaluation of School-Based Character Education Programe Designed to Promote Cooperative Learning and Reduce Anti-Social Behavior, Durham theses, Durham University. 2010. Available at Durham E-Theses Online: http://etheses.dur.ac.uk/180/

[2] Lope, D. (A Critical Analysis of Values Clarification. Montgomery (USA): Apologetics Press,

Inc.

2010. http://www.apologeticspress.org/rr/reprints/critic al-analysis-of-values-cla.pdf

[3] Arthur, J. Traditional Approach to Character education in Britain and America in Handbook of Moral and Character Education edited by Larry Nucci, Darcia Narvaez, and Tobias Krettenauer, New York: Routledge Taylor and Francis Group, 2014.

https://www.routledgehandbooks.com/doi/10.43 24/9780203114896.ch4.

[4] Walker, D. I., \& Thoma, S. J. Moral and Character Education: Cognition, Emotion, and Learning, Education, Change, and Development, Research and Assessment Methods, Educational Theories, and Philosophies, 2017.2 DOI: 10.1093/acrefore/9780190264093.013.119

[5] Hand, M., Symposium on Michael Hand's A Theory of Moral Education. Journal of Beliefs \& Values 41:2, 2020, pp. 227-228. http://doi.org/10.1080/13617672.2020.1717222

[6] Jerome, L. \& Kisby, B. Lessons in character education: incorporating neoliberal learning in classroom resources, Critical Studies inEducation, 2020 DOI: $10.1080 / 17508487.2020 .1733037$

[7] Miller, M., Teaching and Learning in Affective Domain. In M. Orey (Ed.), Emerging perspectives on learning, teaching, and technology. [Retrieved 8 September 2014 from http://epltt.coe.uga.edu/

[8] Badeni, Saparahayuningsih, S. \& Juarsa, O. Development of Attitudes and Character Educational Model based on the 2013 SLTP Curriculum in Bengkulu Province. Research Report: The Research Institute and Community Service Of Bengkulu University, 2017.

[9] Kemendikbud, Materi Pelatihan Guru Implementasi Kurikulum 2013 SMP Ilmu Pengetahuan Sosial [Teacher Training Materials Implementation of the 2013 Curriculum of Social Sciences Middle School], BPSDMP dan PMP Kemendikbud, 2013.

[10] Carlson, N. R., \& Heth, C. D. Psychology the Science of Behavior ( $7^{\text {th }}$ Edition). Ontario, CA: Pearson Education Canada, 2010. pp 20-22. 
[11] Badeni \& Saparahayuningsih, S. An Attitude and Character Instructional Development Based on Curriculum 2013 in Elementary School. Creative Education, 7 (January), 2016. 269-277. DOI: $10.4236 /$ ce.2016.72025.

[12] Borg, W.R. \& Gall, M.D. Gall. Educational Research: An Introduction, Fifth Edition. New York: Longman, 1983.

[13] Anderson and Krathwohl. Bloom's Taxonomy Revised Understanding the New Version of Bloom's Taxonomy: A succinct discussion of the revisions to Bloom's classic cognitive taxonomy by Anderson and Krathwohl and how to use them effectively, 2016. https://quincycollege.edu/content/uploads/Ander son-and-Krathwohl_Revised-BloomsTaxonomy.pdf.

[14] Renkl, A., Atkinson, R. K., Maier, U. H., \& Staley, R. (2002). From example study to problem-solving: Smooth transitions help to learn. Journal of Experimental Education, 70 (4), 293-315.

[15] Cranton, P. Planning Instruction for Adult Learners (3rd ed.).Toronto: Wall \& Hand, M.
(2019). Moral education and the justification of basic moral standards: Replies to Clayton, Stevens, and D'Olimpio. Journal of Moral Education 48:4, 2012. Pp. 529-539. https://doi.org/10.1080/03057240.2019.1626704

[16] Brown, P. C., Roediger III, Henry L., \& Mcdaniel, M. A. Make It Stick: The Science Of Successful Learning. Cambridge, Massachusetts, London, England: The Belknap Press Of Harvard University Press. 2014.

[17] Vygotsky, L. S. Mind in society. Cambridge, MA: Harvard University Press. 1978

[18] NC State University. Edgar Dale's Cone of Experience; 1978. available from http://www.cals.ncsu.edu/agexed/sae/ppt1/sld012 .htm [Accessed October 18, 2005]

[19] Bandura, A. Social Learning Theory, 2019. https://www.instructionaldesign.org/theories/soci al-learning/

[20] Brame, C. Active Learning. Vanderbilt University Center for Teaching. [Retrieved: May 26, 2016. from https://cft.vanderbilt.edu/activelearning/ 